Niniejsza publikacja jest dostęna na licencji Creative Commons. Uznanie autorstwa-Użycie niekomercyjne-Bez utworów zależnych 3.0 Polska. Pewne prawa zastrzė̇one na rzecz autora. Zezwala się na wykorzystanie publikacji zgodnie z licencja-pod warunkiem zachowania niniejszej informacji licencyjnej oraz wskazania autora jako właściciela praw do tekstu. Treść licencji jest dostępna na stronie: http://creativecommons.org/licenses/by-nc-nd/3.0/pl/

Lingwistyka Stosowana 23: 3/2017, 181-195

\author{
Izabela ORCHOWSKA
}

Uniwersytet im. Adama Mickiewicza w Poznaniu

\title{
Kształcenie nauczycieli języków obcych jako interdyscyplinarny przedmiot poznania naukowego. Refleksja metaglottodydaktyczna na temat relacji między glottodydaktyką a pedagogiką
}

\begin{abstract}
:
Foreign language teacher education as an interdisciplinary object of study. Meta-glottodidactic reflection on the relationship between glottodidactics and pedagogy

The aim of the present article is meta-glottodidactic reflection on the choices Polish teaching specialists make when defining and interpreting the interdisciplinary nature of a glottodidactic object of study. The author focuses on the interdisciplinary character of the relationship between glottodidactics and pedagogy as related sciences in foreign language teacher education discourse. What follows is an analysis of the effects that Polish scholars' epistemological choices may have on the consolidation of knowledge within the Polish glottodidactic community. The author also stresses the influence those choices might have on the mutual understanding between specialists representing glottodidactics (both as theory and practice of foreign language education) and pedagogy.
\end{abstract}

\section{Wstęp}

Celem niniejszego artykułu jest refleksja metaglottodydaktyczna nad wyborami polskich glottodydaktyków odnośnie do definiowania i interpretowania interdyscyplinarności przedmiotu poznania w glottodydaktyce. W celu ukonkretnienia mojej refleksji, skoncentruję się na relacji pomiędzy glottodydaktyką a pedagogiką w glottodydaktycznym obszarze kształcenia nauczycieli języków obcych (dalej GOKNJO). Pochylę się zwłaszcza nad konsekwencjami wyborów metaglottodydaktycznych polskich glottodydaktyków dla konsolidacji wiedzy glottodydaktycznej i dla jakości dialogu naukowego pomiędzy glottodydaktykami zainteresowanymi kształceniem nauczycieli języków obcych jako przedmiotem poznania naukowego oraz pomiędzy glottodydaktykami a przedstawicielami nauk pokrewnych.

Problematyka interdyscyplinarności stanowi przedmiot zainteresowania naukowców od początku dwudziestego wieku, a zdaniem Y. Lenoir i L. Sauve (1998: 134) należy wyróżnić dwie główne orientacje w podejściu do interdyscyplinarności: poszukiwanie pewnego rodzaju syntezy konceptualnej ukierunkowanej filozoficznie i zmierzającej do jedności wiedzy oraz podejście instrumentalne, ukierunkowane praktycznie i inspirowane raczej problemami społecznymi, dotychczas nierozwiąza- 
nymi, a nie samą nauką. Interdyscyplinarność w obszarze kształcenia nauczycieli może być definiowana z obu perspektyw. Kształcenie nauczycieli może być bowiem rozumiane zarówno jako przedmiot poznania naukowego, jak i jako praktyka dydaktyczna, ale w niniejszej refleksji metaglottodydaktycznej o GOKNJO najbardziej adekwatne wydaje się być spojrzenie na interdyscyplinarność z perspektywy epistemologicznej glottodydaktyki jako nauki.

Refleksja nad interdyscyplinarnością nauki oczywiście wymaga jednoczesnego zastanowienia się nad pojęciem samej nauki i dyscypliny naukowej. W przypadku GOKNJO konieczne jest zatem uwzględnienie dyskursu metaglottodydaktycznego, który możemy uznać za dyskurs konstytuujący dla glottodydaktycznej wspólnoty naukowej, a tym samym stanowiący fundament dla koncepcji nauki, którą członkowie tej wspólnoty kształtują (zob. D. Maingueneau/ F. Cossutta 1995). Co więcej, można stwierdzić, że glottodydaktycy poprzez dyskurs metaglottodydaktyczny manifestują swoją tożsamość naukową i swój autorytet epistemiczny, które są powiązane $\mathrm{z}$ ich autonomią poznawczą i przynależnością do danej wspólnoty specjalistów (zob. I. Orchowska 2017, w opracowaniu).

Należy podkreślić, że kwestia tożsamości naukowców, jak i autonomii naukowej samej glottodydaktyki jest szczególnie ważna i aktualna w polskim kontekście akademickim, w którym glottodydaktyka nie została jeszcze uznana instytucjonalnie za naukę autonomiczną i włączona do klasyfikacji dziedzin i dyscyplin naukowych (zob. rozporządzenie Ministra Nauki i Szkolnictwa Wyższego z dnia 8 sierpnia 2011 r. w sprawie obszarów wiedzy, dziedzin nauki i sztuki oraz dyscyplin naukowych i artystycznych). Konieczność wyodrębnienia glottodydaktyki jako nauki autonomicznej widzi Polskie Towarzystwo Neofilologiczne, które wystąpiło do Ministerstwa Nauki i Szkolnictwa Wyższego z wnioskiem, aby glottodydaktykę uznać za odrębną dyscyplinę naukową w obszarze nauk humanistycznych (zob. A. Jaroszewska 2014). Warto zwrócić uwagę, że Polskie Towarzystwo Neofilologiczne uzasadniło swój wniosek m.in. stwierdzeniem, że obecne przyporządkowanie glottodydaktyki tzw. językoznawstwu stosowanemu nie odzwierciedla jej rzeczywistego statusu naukowego ani nie sprzyja dalszemu jej rozwojowi. Pisze o tym również W. Wilczyńska (2010: 23) przypominając, że kuratela językoznawstwa stosowanego jest związana z ryzykiem zawężenia zakresu i środków oddziaływania praktyki dydaktycznej w obszarze kształcenia językowego, co jest niebezpieczne dla jej efektywności.

Inicjatywa Polskiego Towarzystwa Neofilologicznego nie doczekała się dotychczas pozytywnej odpowiedzi ze strony Ministerstwa. W konsekwencji, nie jest możliwe uzyskiwanie kolejnych stopni naukowych z glottodydaktyki, a naukowcy prowadzący badania $w$ tym obszarze poznania są kategoryzowani jako językoznawcy i językoznawcy stosowani. W tej sytuacji naukowcy będący członkami glottodydaktycznej wspólnoty naukowej powinni skoncentrować swoje działania (meta)poznawcze i transferencyjne na definiowaniu glottodydaktyki jako nauki, na wyjaśnianiu i akcentowaniu jej specyfiki epistemologicznej. Jest to tym bardziej konieczne, że zgodnie z tym, o czym pisał F. Grucza jeszcze w latach 80. dwudziestego wieku, żadna nauka nie może uzyskać autonomii zewnętrznej (instytucjonalnej), 
zanim nie wytworzy autonomii wewnętrznej (immanentnej), tzn. „zanim nie zdoła się samookreślić", co z warunkuje zresztą jej istnienie jako nauki (F. Grucza 1983: 14). Co więcej, dana nauka, aby wiązać się z innymi naukami, a zatem również, aby wchodzić z innymi naukami w dialog interdyscyplinarny „winna określić się w sposób jak najbardziej rygorystyczny" (F. Grucza 1983: 13). Tymczasem, jak zauważa M. Dakowska (2014: 21), takie kwestie metaglottodydaktyczne, jak: tożsamość i zadania dziedziny, perspektywy rozwoju, specjalizacja jej poddziedzin, polityka badawcza, samoocena dokonań badawczych, relacje z dyscyplinami pokrewnymi, miejsce dydaktyki języków obcych w humanistyce, kryteria naukowości w świetle specyfiki przedmiotu badań, zagadnienia epistemologiczne, problematyka relacji metod jakościowych do ilościowych wciąż wymagają doprecyzowania na gruncie polskiej glottodydaktyki (por. I. Orchowska 2015b).

\section{Podejście do interdyscyplinarności przedmiotu poznania $\mathbf{w}$ glottodydaktyce jako zagadnienie metaglottodydaktyczne kluczowe dla konsolidacji wiedzy $w$ glottodydaktycznym obszarze ksztalcenia nauczycieli języków obcych}

Zjawisko interdyscyplinarności we współczesnych naukach humanistycznych i społecznych bywa nie tylko różnie definiowane, ale również bardzo odmiennie wartościowane jako zjawisko metanaukowe. Co więcej, inaczej przedstawia się historycznie interdyscyplinarność glottodydaktyki i pedagogiki. O ile w dziedzinie nauczania/uczenia się języków obcych i drugich początkowo opierano się na koncepcjach językoznawczych, widząc $w$ nich odpowiedź na pytanie o to, co powinno być przedmiotem kształcenia, a następnie na psychologicznych teoriach uczenia się, to pedagogika miała początkowo ukierunkowanie filozoficzne. Dla przykładu J.F. Herbart nazywał system pedagogiki naukowej pedagogiką filozoficzną (zob. A. Murzyn 2004), podczas gdy glottodydaktycy upatrywali naukowość glottodydaktyki w transferowaniu na jej grunt poznawczy modeli wypracowanych na gruncie językoznawstwa i psychologii uczenia się (zob. M. Dakowska 1987, J. Arabski 1984).

Ponadto współcześni pedagodzy piszą o pedagogice jako nauce społecznej (zob. D. Klus-Stańska 2009), podczas gdy glottodydaktycy sytuują glottodydaktykę na pograniczu nauk humanistycznych i społecznych, określając ją wręcz jako naukę pogranicza (W. Wilczyńska/ A. Michońska-Stadnik 2010: 18). Ma to znaczenie dla rozumienia interdyscyplinarności obu nauk zarówno w wymiarze wiedzotwórczym, jak i na gruncie aplikacji teorii w praktyce dydaktycznej, zwłaszcza w kontekście akademickim. Dla przykładu, w ramach wdrażania od 2012 r. Krajowych Ram Kwalifikacji na neofilologiach, kierunek filologia, obejmujący również specjalność glottodydaktyczną, został jednoznacznie zaklasyfikowany do obszaru nauk humanistycznych, podczas gdy pedagogika została wpisana do obszaru nauk społecznych.

Jednocześnie, jeśli chodzi o GOKNJO, to przedmiot poznania w tym obszarze nauki częściowo pokrywa się z przedmiotem poznania subdyscypliny pedagogiki, jaką jest pedeutologia (por. H. Kwiatkowska 1997). Co więcej, o ile dla pedagogów pedeutologia stanowi subdyscyplinę pedagogiki w ramach dydaktyki ogólnej (zob. D. Klus-Stańska 2009), to dla części polskich glottodydaktyków pedeutologia jest integralną częścią glottodydaktyki (zob. P. Płusa 1992, W. Pfeiffer 2001). 
Należy również podkreślić, że zarówno glottodydaktyka, jak i pedagogika są uznawane za nauki empiryczne, co odróżnia je znacząco od nauk formalnych (matematycznych), do których przynależy m.in. językoznawstwo formalne. W specyficzny sposób wpływa to na definiowanie relacji pomiędzy obiema interesującymi nas tutaj naukami, a także pomiędzy nimi a praktyką kształcenia. I o ile jeszcze w latach 70. dwudziestego wieku F. Grucza (1978) podkreślał różnicę między poznaniem naukowym a intuicyjnym, o tyle dzisiaj, zwłaszcza w dyskursie metapedagogicznym, coraz częściej podkreśla się nie tylko wielość ujęć teoretycznych i interpretacyjnych, ale także przełamanie scjentystycznego myślenia o teorii i praktyce kształcenia (zob. D. Klus-Stańska 2010: 373).

Można stwierdzić, że wieloparadygmatyczność zarówno współczesnej pedagogiki, jak i glottodydaktyki jest dzisiaj faktem (M. Dakowska 2014, I. Orchowska 2015b), ale jest ona postrzegana zarówno jako ich atut, jak i niebezpieczeństwo. Myślę, że bardzo funkcjonalne $\mathrm{w}$ refleksji metanaukowej na ten temat może być odniesienie się do pojęcia chaosu ${ }^{1}$. Jego niezwykle inspirującą analizę z perspektywy opisu dydaktyki zarówno jako subdyscypliny pedagogicznej, jak i praktyki społecznej proponuje D. Klus-Stańska (2010). Pisze ona między innymi o tym, że chaotyczność jako atrybut dydaktyki może w jej wymiarze ontologicznym być witalna, oznaczać wielość i dynamiczną społecznie zmienność, ale również może hamować jej rozwój i obniżać jakość myślenia naukowego, oznaczając nieporozumienia i zamęt, które „hamują rozwój dyscypliny lub czynią praktykę społeczną nieadekwatną wobec intencji jej autorów lub wobec kultury, w której funkcjonowaniu ma służyć edukacja" (D. Klus-Stańska 2010: 10).

Takie rozumienie chaotyczności skłania do dostrzeżenia analogii pomiędzy chaosem $\mathrm{w}$ pedagogice a eklektyzmem $\mathrm{w}$ glottodydaktyce i w praktyce dydaktycznej, o którym pisze C. Puren (1994). Po pierwsze, jeśli chodzi o eklektyzm w nauczaniu/uczeniu się języków to jest on, zdaniem C. Purena, odpowiedzią na złożoność sytuacji kształcenia językowego i wpisuje się w paradygmat złożoności, wprowadzony przez E. Morin (1990). Jednocześnie C. Puren opowiada się za ukonstytuowaniem się eklektyzmu opartego na zachowaniu niezbędnej, minimalnej spójności, na zdefiniowaniu zasady otwartej spójności i przeciwstawia go spójności, która ogranicza wielowymiarowość sytuacji dydaktycznej. Innymi słowy eklektyzm metodyczny powinien oznaczać świadomy wybór praktyk nauczania, przy kierowaniu się kryterium skuteczności, co warunkowane jest szerokimi i zróżnicowanymi kompetencjami dydaktycznymi i metodycznymi nauczyciela. C. Puren (1994) dostrzega jednak ryzyko eklektyzmu epistemologicznego, który może stać się dla niektórych nauczycieli pretekstem do nauczania wszystkiego po trochu, na różne sposoby i prawie wszystkich uczniów, co wiąże się z brakiem spójności i ciągłości.

\footnotetext{
${ }^{1}$ Pierwsi teorią chaosu zainteresowali się filozofowie, którzy uznali jej wpływ na niektóre stanowiska ontologiczne, takie jak monizm, indeterminizm, ewolucjonizm. Obecnie dominuje pogląd, że teoria chaosu stanowi nie tylko nowy paradygmat w nauce, ale także inspirację do badań filozoficznych nad rzeczywistością (A. Bodanko 2013: 44).
} 
Taki eklektyzm byłby również niebezpieczny w działalności naukowej, zwłaszcza gdy mamy do czynienia $\mathrm{z}$ interdyscyplinarnym przedmiotem poznania, jakim jest kształcenie nauczycieli języków obcych. W. Wilczyńska (2010) przestrzega przed dążeniem autorów publikacji naukowych do wyczerpania tematu poprzez przytaczanie luźno tylko ze sobą powiązanych koncepcji, zaczerpniętych z innych dyscyplin naukowych, co prowadzi do niespójności w ujmowaniu problemu, powierzchowności refleksji i zbytecznej intelektualizacji.

Odmienne stanowisko zajmuje J. Zając (2010), odwołując się do paradygmatu systemowego, który funkcjonuje w piśmiennictwie pedagogicznym i jest ukierunkowany na integrację nauki, przezwyciężenie barier między dyscyplinami oraz całościowe traktowanie badanych obiektów jako systemów otwartych. Ma to pozwolić uniknąc punktowego, niekompletnego i mało inspirującego oglądu rzeczywistości. Ponadto dla J. Zając (2008), interdyscyplinarność w kształceniu nauczycieli oznacza wypracowanie postawy otwartości na wszystko, co jest niezbędne, konieczne lub użyteczne w zawodzie nauczyciela. Prowadzi do wrażliwości w stosunku do drugiego człowieka, przy zachowaniu świadomości samego siebie, do akcentowania rozwiązań zindywidualizowanych i twórczych, do rozwijania postawy krytycznej, korzystania z doświadczeń własnych i cudzych, do produkowania wiedzy, a nie tylko do jej bezrefleksyjnej absorpcji. W konsekwencji nauczyciele powinni być kształceni w taki sposób, aby sami mogli decydować, do dorobku jakich nauk potrzebują odnosić się w danym momencie, tak aby osiągnąc sukces w procesie dydaktycznym.

Można stwierdzić, że kryterium skuteczności praktycznej jest kluczowe zarówno w eklektyzmie zdefiniowanym przez C. Purena (1994), jak i w koncepcji interdyscyplinarności proponowanej przez J. Zając $(2008,2010)$. Co więcej, w obu tych ujęciach granice pomiędzy myśleniem naukowym a praktycznym niejako zanikają. Tymczasem w glottodydaktyce jako nauce prymarne są cele poznawcze, a konstruowanie wiedzy praktycznie użytecznej jest postrzegane jako wtórny efekt naukowej pracy poznawczej (M. Dakowska 2010). Ponadto, jak pisał F. Grucza (1978), transformowanie nauki języków obcych uzasadnione jedynie intuicją należy oddzielić od jej racjonalizacji sensu stricte, czyli efektywizacji będącej rezultatem badań naukowych. Dlatego również refleksja nad interdyscyplinarnością przedmiotu poznania w GOKNJO powinna, moim zdaniem, uwzględniać epistemologiczną specyfikę glottodydaktyki jako nauki, a zwłaszcza wymiar wiedzotwórczy w funkcjonowaniu glottodydaktycznej wspólnoty naukowej.

Zasadnicze z punktu widzenia metaglottodydaktyki wydaje się zatem być pytanie o to, jaka koncepcja interdyscyplinarności glottodydaktyki sprzyja rozwojowi współczesnej glottodydaktyki. W. Wilczyńska i A. Michońska-Stadnik (2010) uważają, że kluczowe znaczenie dla rozwoju nauki ma wysoki poziom autonomii w inicjowaniu i prowadzeniu prac badawczych. Autonomia poznawcza badacza umożliwia na drodze wymiany naukowej spójne, a jednocześnie ciągle otwarte na nowe elementy budowanie wiedzy $\mathrm{w}$ danym zakresie. W związku $\mathrm{z}$ tym każdy badacz powinien mieć świadomość, że „nie tylko realizuje określone zadanie badawcze czy zaspokaja swoją pasję poznawczą, ale de facto włącza się także w komunikację naukową jako proces budowania wiedzy" (W. Wilczyńska/ A. Michońska-Stadnik 2010: 83). W 
przypadku transferencji wiedzy naukowej, glottodydaktycy jako naukowcy muszą jednocześnie uwzględniać normy właściwej dla tego rodzaju komunikacji specjalistycznej, a ze względu na wieloparadygmatyczność teoretyczną i metodologiczną glottodydaktyki konieczne jest ,każdorazowe definiowanie przez glottodydaktyków w swoich publikacjach naukowych ich usytuowania epistemologicznego, a także odniesienie przedmiotu ich refleksji naukowej od ogólnej problematyki glottodydaktycznej" (I. Orchowska 2015b: 96).

A jednak lektura artykułów sytuujących się w GOKNJO i opublikowanych na łamach „Neofilologa” ${ }^{2}$ skłania do stwierdzenia, że polscy glottodydaktycy rzadko precyzują, jaki jest wkład ich refleksji poznawczej w całościowy rozwój glottodydaktyki jako nauki. Co więcej, dyskurs glottodydaktyczny dotyczący kształcenia nauczycieli jest najczęściej ukierunkowany na prezentowanie własnej praktyki kształcenia z punktu widzenia eksperta w obszarze kształcenia językowego, a jeśli ta praktyka jest poddawana ocenie, to najczęściej w oparciu o rezultaty ankiet adresowanych do studentów jako przyszłych nauczycieli JO (por. I. Orchowska 2015a i b).

Należy zauważyć, że polska wspólnota glottodydaktyczna jest wspólnotą bardzo zróżnicowaną i zhierarchizowaną, co ma bezpośredni wpływ na heterogeniczność dyskursu, a tym samym na jakość dialogu naukowego w tym obszarze poznania. Dla przykładu, doświadczonym naukowcom, uznanym autorytetom epistemicznym $\mathrm{w}$ dziedzinie glottodydaktyki udaje się za pośrednictwem swojego dyskursu osadzonego w GOKNJO dokonywać konsolidacji wiedzy glottodydaktycznej i przyczyniać się do całościowego rozwoju glottodydaktyki jako nauki (zob. E. Zawadzka-Bartnik 2014, A. Michońska-Stadnik 2013). Początkujący badacze nie podejmują natomiast na ogół wyzwań metaglottodydaktycznych i albo wpisują się w ujęcia epistemologiczne charakterystyczne dla pedagogiki, albo koncentrują się na kształceniu nauczycieli języki obcych jako działalności praktycznej, nie wiążąc swojej refleksji z jakąkolwiek teorią ogólną glottodydaktyki jako nauki. W konsekwencji dyskurs glottodydaktyczny jest stosunkowo często dyskursem zorientowanym pedagogicznie, bądź też dyskursem z pogranicza nauk. Niedoświadczonym badaczom zdarza się również dążyć do wyczerpującego ujęcia podejmowanych problemów, które objęłoby wszystkie możliwe perspektywy i naświetlenia. Tymczasem wielość odniesień zastępuje pogłębioną analizę pojęć i koncepcji, zorientowaną epistemologicznie interpretację, a w konsekwencji również uniemożliwia syntezę i konsolidację wiedzy glottodydaktycznej.

Interdyscyplinarność przedmiotu poznania w GOKNJO przyczynia się do tego, że wpływ pedagogiki jako nauki jest widoczny w polskojęzycznym dyskursie glottodydaktycznym zarówno na poziomie teorii i modeli odniesienia, jak i w traktowaniu przez polskich glottodydaktyków kwestii teoretycznych i metodologicznych. Doprowadziło to m.in. do transferu na grunt refleksji glottodydaktycznej pojęć i koncepcji pedagogicznych, często bez adaptacji tych konstruktów do specyfiki epistemologicznej glottodydaktyki. Za przykład mogą posłużyć tu pojęcia praktyki ${ }^{2}$ „Neofilolog” to czasopismo naukowe Polskiego Towarzystwa Neofilologicznego, które ma
na celu popularyzowanie wiedzy w dziedzinie glottodydaktyki. 
refleksyjnej (por. D. Schön 1983, E. Zawadzka-Bartnik 2014), teorii osobistych nauczyciela (por. C. Kallenbach 1996, E. Zawadzka 2004, A. Michońska-Stadnik 2013), a nawet pojęcie teorii chaosu (por. D. Klus-Stańska 2009, B. Karpińska-Musiał 2015).

Przywołane powyżej problemy z konsolidacją wiedzy glottodydaktycznej zainspirowały mnie do zastanowienia się nad tym, jak powinno wyglądać wzorcowe traktowanie interdyscyplinarności przedmiotu poznania w glottodydaktyce i czy takie wzorce możemy odnaleźć w polskim dyskursie glottodydaktycznym, a metaanaliza artykułów opublikowanych na łamach „Neofilologa” pozwoliła mi wyróżnić trzy główne podejścia glottodydaktyków do interdyscyplinarności GOKNJO: interdyscyplinarność rozumiana jako interdyscyplinarność przedmiotu poznania w glottodydaktyce jako empirycznej nauce autonomicznej; interdyscyplinarność kształcenia nauczycieli języków obcych definiowana na gruncie szeroko rozumianej humanistyki; traktowanie interdyscyplinarności kształcenia nauczycieli języków obcych wyłącznie w kategoriach praktyki kształcenia. W dalszej części mojego artykułu postaram się wyjaśnić, dlaczego i pod jakimi warunkami tego typu podejścia mogą sprzyjać konsolidacji wiedzy i dialogowi naukowemu wewnątrz wspólnoty glottodydaktycznej.

\section{Jakie sposoby traktowania interdyscyplinarności kształcenia nauczycieli ję- zyków obcych sprzyjają konsolidacji wiedzy i dialogowi naukowemu ?}

Przywołane powyżej podejścia do interdyscyplinarności GOKNJO wymagają od naukowców jako autorów publikacji naukowych osiągnięcia zaawansowanej glottodydaktycznej świadomości epistemologicznej i autonomii poznawczej, a także orientacji w ogólnych kwestiach metanaukowych (dwa pierwsze podejścia), bądź też umiejętności analizowania problemu dydaktycznego z perspektywy glottodydaktycznej, nawet jeśli w celu jego zdefiniowania odnoszą się oni również do wiedzy z dyscyplin pokrewnych, takich jak pedagogika, filozofia, psychologia itp.

Odnoszenie się do koncepcji glottodydaktyki jako nauki empirycznej aspirującej do autonomii i opartej na założeniach programu tzw. „normalnej” nauki T. Kuhna (1962), ale zaadaptowanej do specyfiki epistemologicznej glottodydaktyki oznacza, że wszelkie teorie, koncepcje, modele transferowane na grunt glottodydaktyki z obszarów nauk pokrewnych glottodydaktyce powinny być adaptowane do specyfiki teoretycznej i metodologicznej glottodydaktyki. Takie ujęcie interdyscyplinarności w GOKNJO ilustruje na przykład propozycja modelowania procesu rozwijania glottodydaktycznej świadomości przedmiotowej i epistemologicznej (przyszłych) nauczycieli języków obcych (zob. B. Karpińska-Musiał/ I. Orchowska 2014). Zamiast dokonania transferu na grunt GOKNJO modeli kształcenia nauczycieli wypracowanych na gruncie pedagogiki, przyjmuje się za główne filary rozwoju kompetencji zawodowej przyszłego nauczyciela języków obcych glottodydaktyczną świadomość 
epistemologiczną i glottodydaktyczną świadomość przedmiotową, co ujmuje rysunek umieszczony na następnej stronie ${ }^{3}$.

Warto w tym miejscu sprecyzować, że kompetencja zawodowa nauczyciela języków obcych w naszym ujęciu (B. Karpińska-Musiał/ I. Orchowska 2014) to zespół osobistych umiejętności, wiedzy, postaw i wartości, które dany podmiot dynamicznie dopasowuje do celów, warunków i rodzaju podejmowanych działań dydaktycznych, wyrażając w ten sposób swoje podmiotowe doświadczenia, wiedzę i relacje z innymi uczestnikami układu glottodydaktycznego (por. W. Wilczyńska 2002). Tym samym, rozwój zawodowy nauczyciela języków obcych stanowi integralną część procesu kształtowania jego tożsamości zawodowej i osobistej. Ponadto atrybutem kompetencji zawodowej nauczyciela języków obcych powinna być antycypacja, powiązana $\mathrm{z}$ umiejętnością dokonywania interpretacji, wyborów, wartościowania $\mathrm{i}$ ewaluacji różnych sytuacji dydaktycznych (zob. E. Zawadzka 2004), przy czym wybory przyszłego nauczyciela języków obcych dokonują się na etapie kształcenia formalnego $\mathrm{w}$ drodze dialogu $\mathrm{z}$ nauczycielem akademickim jako swego rodzaju mediatorem i ekspertem w dziedzinie nauczania/uczenia się języków obcych.

To glottodydaktyczna świadomość epistemologiczna i glottodydaktyczna świadomość przedmiotowa warunkują, naszym zdaniem, dynamikę w rozwoju kompetencji zawodowej nauczyciela języków obcych. Glottodydaktyczna świadomość epistemologiczna to bowiem świadomość specyfiki teoretycznej i metodologicznej glottodydaktyki, stanowiąca warunek aktywnej przynależności do glottodydaktycznej wspólnoty naukowej i świadomego interpretowania i współtworzenia złożonej rzeczywistości edukacyjnej w procesie nauczania/uczenia się języków obcych (B. Karpińska-Musiał/ I. Orchowska 2014), podczas gdy glottodydaktyczna świadomość przedmiotowa odnosi się do sposobu, w jaki uczestnicy procesu dydaktycznego (re)konstruują reprezentacje odnoszące się do przedmiotów szkolnych i ich nauczania w czterech wymiarach: przestrzeni przepisów, przestrzeni zaleceń, przestrzeni wyobrażeń uczestników procesu dydaktycznego, przestrzeni działań praktycznych.

Definiowanie interdyscyplinarności GOKNJO na gruncie szeroko rozumianej humanistyki oznacza z kolei przyjęcie za punkt wyjścia perspektywy transdyscyplinarnej, a następnie skonfrontowanie tak szeroko zakrojonej koncepcji ze specyfiką kształcenia językowego. Taki dialog naukowy z przedstawicielami nauk pokrewnych i innymi glottodydaktykami wiąże się z eksplicytnym przywołaniem osadzenia epistemologicznego poszczególnych dyskursów na temat kształcenia nauczycieli, a tym samym wymaga teoretycznego rozeznania na poziomie wielu dyscyplin, jak i w ogólnej metodologii nauk. W konsekwencji takie podejście powinno być zarezerwowane dla najbardziej wybitnych i doświadczonych badaczy, będących autorytetami epistemicznymi wewnątrz danej wspólnoty naukowej.

${ }^{3} \mathrm{~W}$ rysunku zastosowałam dwa symbole: NA (nauczyciel akademicki) i N/U JO (nauczanie/uczenie się języków obcych). 


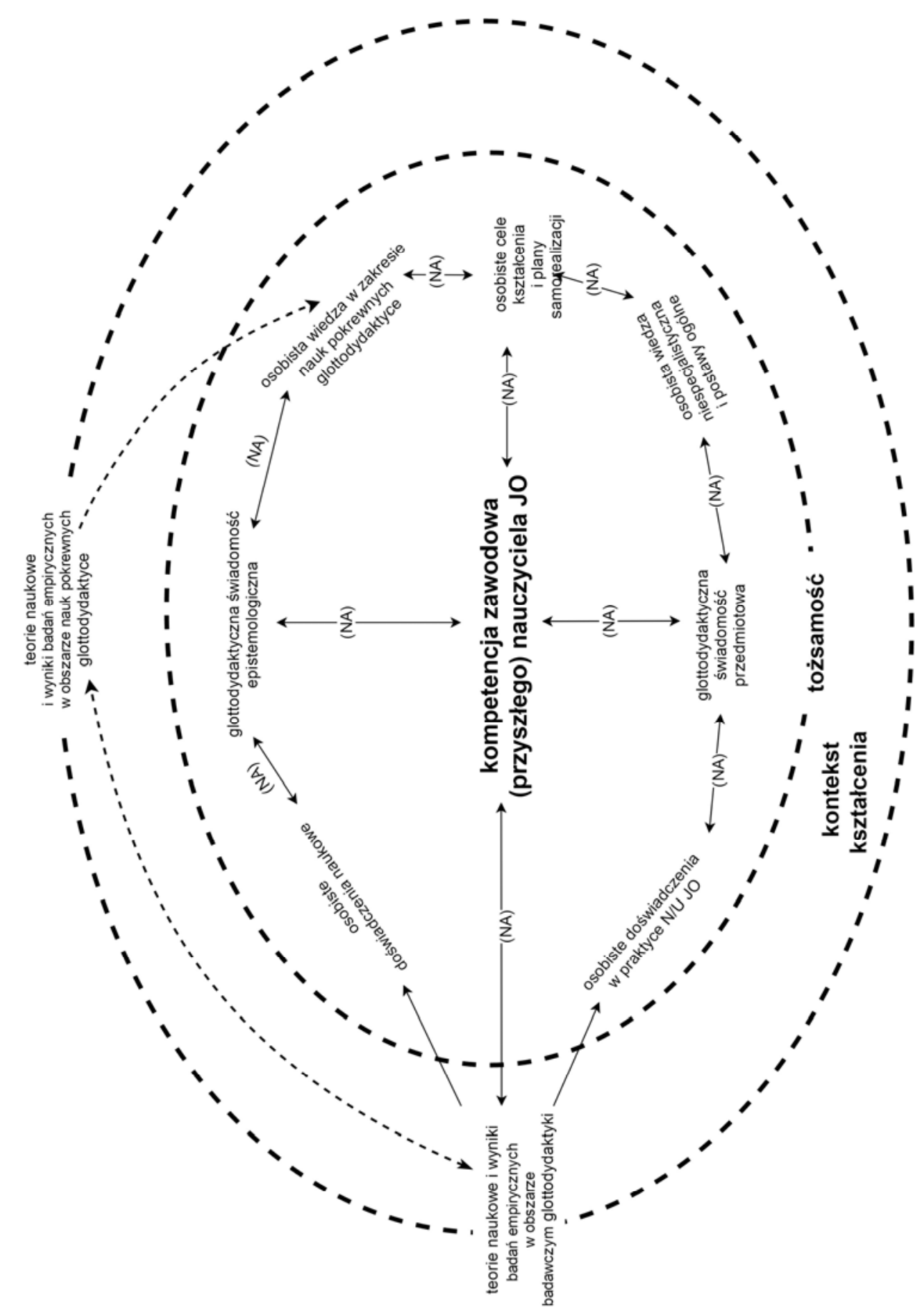

Rysunek 1. Modelowe ujęcie czynników warunkujących rozwój kompetencji zawodowej (przyszłego) nauczyciela języków obcych - opracowanie własne na podstawie B. Karpińska-Musiat/I. Orchowska (2014.) 
W przywołane powyżej podejście wpisuje się na przykład metasynteza kategorii refleksji w zawodzie nauczyciela na gruncie szeroko rozumianej edukacji, przy jednoczesnym uwzględnieniu specyfiki GOKNJO, dokonana przez E. Zawadzą-Bartnik (zob. E. Zawadzka-Bartnik 2014). Ta doświadczona glottodydaktyk za punkt wyjścia dla swojej metasyntezy przyjęła przypomnienie tego, jak pojęcie refleksji zostało zdefiniowane na gruncie pedagogiki, jakie właściwości zostały mu przypisane $\mathrm{i}$ jak to pojęcie łączy się z tzw. refleksyjną praktyką. Autorka wskazała na nadmierne uproszczenie pojęcia refleksji, na jego nadużywanie bez uwzględnienia jego głębokiego sensu. Zwróciła zwłaszcza uwagę na zawężenie pojęcia refleksji głównie do obszarów instrumentalnych, na pominięcie refleksji nad sobą w zawodzie i życiu osobistym, nad tym, czego uczymy, a co powinno być głównym celem nauczania, nad ukrytym programem oraz na blokadę, jaką w uruchomieniu refleksji stanowią tzw. teorie osobiste nauczycieli.

Następnie E. Zawadzka-Bartnik skoncentrowała się na trudnościach w realizacji idei refleksji będących pokłosiem rozproszenia wiedzy teoretycznej podczas kształcenia nauczycieli i nieuwzględnienia specyfiki nauczania języków obcych. Podkreśliła konieczność posiadania przez nauczyciela języków obcych specyficznego rodzaju wiedzy profesjonalnej, ,będącej wynikiem badań glottodydaktyki i stwarzającej nauczycielowi szansę wieloaspektowości poznania, analizy, weryfikacji i dostosowywania działań dydaktycznych do stale zmieniającej się sytuacji” (E. ZawadzkaBartnik 2014: 13). Poddała krytyce nieuwzględnienie specyfiki językowej, choćby w formie aneksu do standardów kształcenia nauczycieli języków obcych, co doprowadziło do dominacji zajęć ściśle psychologiczno-pedagogicznych nad glottodydaktycznymi bez oczekiwanej aplikacji teorii komunikacyjnych, psychologicznych i pedagogicznych do nauczania języków obcych. W konsekwencji idea refleksyjności nie jest, jej zdaniem, realizowana, a utrwalane są nie zawsze słuszne teorie osobiste nauczycieli i nie zawsze efektywne działania dydaktyczne. Dodatkowo ideologia rynkowa sprowadza problemy edukacji do kwestii rachunku ekonomicznego, promując model szybkiego uzyskiwania kwalifikacji nauczycielskich.

Resumując sposób interpretowania interdyscyplinarności GOKNJO przez E. Zawadzką-Bartnik (2014) można stwierdzić, że złożoność przedmiotu poznania i kształcenia $\mathrm{w}$ tym obszarze glottodydaktyki wiąże się z poznawaniem teorii i koncepcji kształcenia wypracowanych na gruncie nauk pokrewnych, a zwłaszcza z przyswojeniem i zrozumieniem zasad pedagogiki humanistycznej ze strony nauczycieli języków obcych. Nie wyklucza to konieczności kształcenia ich w zakresie rozumienia specyfiki kształcenia językowego. Specjalizacja w kształceniu językowym winna zatem wpisywać się w filozofię kształcenia, odwołującą się do wartości uniwersalnych, sprzyjających samorealizacji i wielostronnemu rozwojowi człowieka (E. Zawadzka-Bartnik 2014: 20).

O ile podejście E. Zawadzkiej-Bartnik (2014) do interdyscyplinarności wpisuje się w ramy glottodydaktyki jako nauki, na gruncie polskojęzycznego dyskursu glottodydaktycznego w GOKNJO mamy również do czynienia z traktowaniem interdyscyplinarności kształcenia nauczycieli wyłącznie w kategoriach praktyki kształcenia, a nie jako przedmiotu poznania naukowego. Takie prakseologiczne nastawienie jest 
ukierunkowane przede wszystkim na rozwijanie postawy otwartości u nauczycieli języków obcych na dorobek nie tylko różnych nauk, ale i źródeł nienaukowych, dotyczących kształcenia językowego, co ma wpłynąć na optymalizację procesu kształcenia.

W tego typu dyskursie można dostrzec pewne upraktycznienie w podejściu do wiedzy odnoszącej się do kształcenia nauczycieli, w czym upatrywałabym zresztą wpływ pedagogiki, do której zasobów polscy glottodydaktycy często sięgają, nie uwzględniając zresztą na ogół odmienności epistemologicznej pomiędzy glottodydaktyką a pedagogiką i innymi naukami pokrewnymi. Może się to wiązać z profilem zawodowym członków polskiej wspólnoty glottodydaktycznej, która liczy coraz więcej praktyków, dla których priorytetem są efekty kształcenia językowego, a wszelka racjonalizacja naukowa $\mathrm{w}$ obszarze badawczym glottodydaktyki powinna być im podporządkowana. W uzasadnieniu tego typu postulatów trudno zresztą oddzielić poglądy osobiste autorów od twierdzeń zaczerpniętych z teorii naukowych. Dla przykładu, A. Strzałka (2004), pisząc o postulatach dotyczących miejsca kultury w nauczaniu języka obcego, które należy jej zdaniem uświadomić przyszłym i praktykującym nauczycielom, przywołuje w bibliografii naukową literaturę przedmiotu, ale jednocześnie w samym tekście swojego artykułu stwierdza, że jej refleksja jest oparta na wynikach badań własnych i na jej doświadczeniu jako wykładowcy w pracy z nauczycielami i studentami (por. I. Orchowska 2015b).

Co więcej, w 17 artykułach na 60, które zostały opublikowane na łamach „Neofilologa" i których metaanalizy dokonałam (I. Orchowska 2015b) brakuje jakiegokolwiek odniesienia do teorii naukowych jako podstawy do osadzenia epistemologicznego prezentowanych w nich koncepcji kształcenia i/lub badań empirycznych, a jeśli autorzy ci przywołują teorie naukowe, to tylko jako teorie, które powinny być przedmiotem kształcenia nauczycieli. Nie są one natomiast traktowane jako odniesienia teoretyczne mające usytuować refleksję naukową w GOKNJO (por. L. Piasecka 1996).

Jak zauważa M. Malewski (2002: 49-50), ,praktyczność to cecha wiedzy nadawana jej przez praktyków, którzy doświadczając rozlicznych trudności, próbują je pokonać z wykorzystaniem odnoszących się do nich teorii”. A tymczasem teoria pedagogiczna „nie jest w stanie zaoferować wiedzy technologicznie niezawodnej” (M. Malewski 2002: 50), ponieważ teorie, twierdzenia i prawa, jakimi dysponują nauki humanistyczne i społeczne, mają charakter probabilistyczny. Co więcej, podejście do wiedzy naukowej wielu współczesnych glottodydaktyków przypomina, moim zdaniem, podejście studentów pedagogiki, o którym pisze E. Cyrańska (2015: 157-158). Cechuje je wiara w praktyczność pedagogiki i jej metodyczny wymiar, jest ono także oparte na przekonaniu, że praktyczna wiedza pedagogiczna jest wiedzą pewną. Takie podejście odzwierciedla niejako osadzenie w paradygmacie pedagogiki instrumentalnej, który funkcjonuje pośród innych paradygmatów na gruncie polskiej pedagogiki, a jednocześnie stanowi konkurencję dla paradygmatu humanistycznego (por. B. Karpińska-Musiał/ I. Orchowska 2014).

W. Wilczyńska i A. Michońska-Stadnik (2010: 59) wyróżniają dwa ogólne kierunki badań glottodydaktycznych: badania ukierunkowanie poznawczo, związane z 
nastawieniem na tworzenie nowej wiedzy, oraz badania ukierunkowane prakseologicznie, nastawione na większą efektywność praktyczną działań w zakresie nauczania/uczenia się języków. To właśnie w tę drugą kategorię badań glottodydaktycznych wpisuje się prakseologiczne podejście do interdyscyplinarności GOKNJO. Co więcej, moja dotychczasowa metaanaliza artykułów polskich glottodydaktyków sytuujących się w GOKNJO, które zostały opublikowane na łamach „Neofilologa” w latach 1990-2010 wskazuje, że publikacje te są w większości ukierunkowane właśnie na optymalizację kształcenia nauczycieli, podczas gdy wyzwania wiedzotwórcze są w nich stosunkowo rzadko podejmowane (I. Orchowska 2015b).

Oczywiście glottodydaktyka jako nauka empiryczna nie może pozostać obojętna wobec oczekiwań społecznych, a optymalizacja i efektywność kształcenia językowego to główne wyzwania, jakie współczesne społeczeństwo stawia przed glottodydaktykami, sankcjonując niejako wszelką refleksję glottodydaktyczną, ukierunkowaną prakseologicznie. Nie możemy jednak zapominać o różnicy pomiędzy działalnością naukową a działalnością praktyczną, a tym samym całościowo zastępować cele poznawcze glottodydaktyki doraźnymi celami ukierunkowanymi wyłącznie na skuteczność działania.

Warto tutaj podkreślić rozróżnienie pomiędzy poznaniem naukowym a poznaniem potocznym w obszarze nauczania/uczenia się oraz kształcenia nauczycieli. Jak piszą W. Wilczyńska i A. Michońska-Stadnik (2010: 16), wiedza osobista będąca podstawą poznania potocznego jest mniej lub bardziej subiektywna, oparta zarówno na informacjach z zewnątrz, jak i na własnych doświadczeniach, a także na naszych domysłach i zdrowym rozsądku, podczas gdy nauka jest działaniem wspólnym, którego podmiotem jest zbiorowość uczonych wszystkich krajów i epok. Celem nauki jest systematyczny opis rzeczywistości, a granice jej poznania wyznacza dostępność poznania i skuteczność stosowanej metodologii. W poznaniu potocznym koncentrujemy się natomiast na celach doraźnych i polegamy na intuicji. Jeśli w GOKNJO działalność transferencyjna glottodydaktyków będzie zatem odnosiła się wyłącznie do optymalizacji kształcenia nauczycieli, a budowanie modeli ich kształcenia i teorii wyjaśniających uwarunkowania kształcenia zostanie pominięte, to ten obszar poznania będzie trzeba usytuować poza granicami glottodydaktyki jako nauki. Poza tym nie będzie to sprzyjało dialogowi naukowemu pomiędzy glottodydaktykami, a w konsekwencji zablokuje rozwój glottodydaktyki jako nauki autonomicznej.

Konkludując należy stwierdzić, że interdyscyplinarność GOKNJO można definiowane na różne sposoby, ale powinny to być podejścia wzajemnie uzupełniające się i sprzyjające konsolidacji wiedzy na gruncie glottodydaktyki. Jeśli natomiast interdyscyplinarność będzie odnosiła się wyłącznie do praktyki dydaktycznej, a zostanie pominięte jej rozumienie $\mathrm{w}$ znaczeniu dialogu interdyscyplinarnego glottodydaktyków jako naukowców z przedstawicielami nauk pokrewnych, to GOKNJO będzie mógł być definiowany i traktowany wyłącznie jako sfera działalności praktycznej. Ponadto nawet ukierunkowanie na optymalizację kształcenia językowego i dążenie do jego kompleksowej analizy, powinno być dokonywane z perspektywy epistemologicznej glottodydaktyki i uwzględniać uwarunkowania właściwe dla funkcjonowania glottodydaktycznego układu komunikacyjnego. 


\section{Uwagi końcowe}

Podsumowując niniejszą refleksję metaglottodydaktyczną chciałabym podkreślić, że dialog pomiędzy glottodydaktykami oraz między glottodydaktykami a pedagogami w GOKNJO jest konieczny, ale powinien to być dialog naukowców świadomych specyfiki epistemologicznej reprezentowanej przez siebie nauki i odmienności obu nauk pokrewnych, pomimo pozornych zbieżności terminologicznych, konceptualnych, metodologicznych.

Specyfika epistemologiczna glottodydaktyki odróżnia ją od pedagogiki, chociażby ze względu na fakt, że przedmiotem poznania dla pedagogów jest edukacja w szerokim tego terminu znaczeniu i to w relacji do wychowania, podczas gdy glottodydaktycy widzą przedmiot swoich zainteresowań naukowych w nauczaniu/uczeniu się języków obcych i kształceniu specyficznej grupy nauczycieli, jaką są nauczycieli języków obcych. Nie bez znaczenia jest zresztą fakt, że w Polsce dziedziną zajmującą się kształceniem nauczycieli języków obcych była prymarnie neofilologia i że dopiero od lat 70. XX wieku wpisano ten przedmiot poznania w obszar badawczy glottodydaktyki jako nauki. Nie wyklucza to oczywiście z glottodydaktycznej refleksji nad kształceniem nauczycieli języków obcych wymiaru aksjologicznego (zob. E. Zawadzka-Bartnik 2014).

Glottodydaktycy, którzy angażują się w naukowy dialog interdyscyplinarny, powinni zdawać sobie sprawę z tego, w jaki sposób osadzenie epistemologiczne refleksji poznawczych, sytuujących się w różnych obszarach nauki, wpływa na interpretację podejmowanych przez naukowców problemów. Oczywiście wyklucza to podejście powierzchowne do zagadnień naukowych, a implikuje rozeznanie teoretyczne i metodologiczne na poziomie nauk, do których dorobku dany dialog naukowy nawiązuje. Co więcej, koniecznym wydaje się, aby glottodydaktycy, dokonując swoich wyborów epistemologicznych brali pod uwagę nie tylko własne preferencje poznawcze, ale również swoje miejsce wewnątrz glottodydaktycznej wspólnoty naukowej, która, jak każda wspólnota naukowa, jest zhierarchizowana, a status eksperta wymaga długiego procesu (samo)kształcenia, poznawania i współtworzenia własnej dziedziny nauki w jej poszczególnych zakresach oraz pewnego poziomu zaawansowania własnej autonomii poznawczej u badacza.

\section{Bibliografia}

Arabski, J. (1984), Psychologiczne podstawy glottodydaktyki, (w:) E. Banasik (red.), VII Ogólnopolskie Sympozjum Neofilologiczne. Wybrane referaty i doniesienia. Katowice, 5-14.

Bodanko, A. (2013), Czy teoria chaosu będzie wykorzystana w pedagogice?, (w:) „Nauczyciel i Szkoła” 1 (53), 43-54.

Cyrańska, E. (2015), Wiedza i sposób jej zdobywania - oczekiwania studentów pedagogiki. Możliwość przekladów międzyparadygmatycznych bez konieczności ich wartościowania, (w:) D. Urbaniak-Zając/ J. Piekarski (red.), Akademickie kształcenie pedagogów w procesie zmiany. Perspektywy teoretyczne i doświadczenia absolwentów. Kraków, 143-160. 
Dakowska, M. (1987), Funkcje lingwistyki $w$ modelach i procesach glottodydaktycznych. Warszawa.

Dakowska, M. (2010), W poszukiwaniu wiedzy praktycznie użytecznej. O dojrzewaniu glottodydaktyki jako dziedziny akademickiej, (w:) „Neofilolog” 34, 9-19.

Dakowska, M. (2014), O rozwoju dydaktyki języków obcych jako dyscypliny naukowej. Warszawa.

Grucza, F. (1978), Glottodydaktyka w świetle modeli komunikacji językowej, (w:) F. Grucza (red.), Teoria komunikacji językowej a glottodydaktyka. Warszawa, 7-26.

Grucza, F. (1983), Zagadnienia metalingwistyki. Lingwistyka - jej przedmiot, lingwistyka stosowana. Warszawa.

Jaroszewska, A. (2014), O glottodydaktyce słowami glottodydaktyków, (w:) „Języki Obce w Szkole" 4, 52-66.

Kallenbach, Ch. (1996), Subjektive Theorien: Was Schüler und Schülerinnen über Fremdsprachenlernen denke. Tübingen.

Karpińska-Musiał, B. (2015), Międzykulturowość w glottodydaktyce. Gdańsk.

Karpińska-Musiał, B./ I. Orchowska (2014), Świadomość przedmiotowa i epistemologiczna nauczyciela - refleksyjnego praktyka z perspektywy polskiej glottodydaktyki, (w:) „Neofilolog” 43/1, 25-38.

Klus-Stańska, D. (2009), Paradygmaty współczesnej dydaktyki-poszukiwanie kwiatu paproci czy szansa na tożsamość teoretyczno-metodologiczna??, (w:) L. Hurło/ D. Klus-Stańska/ M. Łojko (red.), Paradygmaty współczesnej dydaktyki. Kraków, 11-23.

Klus-Stańska, D. (2010), Dydaktyka wobec chaosu pojęć i zdarzeń. Warszawa.

Kuhn, T. (1962), The Structure of Scientific Revolutions. Chicago.

Kwiatkowska, H. (1997), Edukacja nauczycieli. Konteksty - kategorie - praktyki. Warszawa.

Lenoir, Y./ L. Sauve (1998), De l'interdisciplinarité scolaire à l'interdisciplinarité dans la formation à l'enseignement: un état de la question, (w:) „Revue Française de Pédagogie" 124, 121-146.

Maingueneau, D./ F. Cossutta (1995), L'analyse des discours constituants, (w:) „Langages” 117, 112-125.

Malewski, M. (2002), Niepewność wiedzy - zawodność edukacyjnej praktyki, (w:), J. Piekarski/ E. Cyrańska/ D. Urbaniak-Zając (red.), Granice autonomii teorii i praktyki edukacyjnej, Łódź, 49-61.

Michońska-Stadnik, A. (2013), Teoretyczne i praktyczne podstawy weryfikacji wybranych teorii subiektywnych $w$ kształceniu nauczycieli języków obcych. Wrocław.

Morin, E. (1990), Introduction à la pensée complexe. Paris.

Murzyn, A. (2004), Johann Friedrich Herbart i jego miejsce w kontekście pokantowskiej myśli idealistycznej. Kraków.

Orchowska, I. (2015a), O transferencji wiedzy naukowej i subiektywnych pogladów na temat ksztatcenia nauczycieli języków obcych na podstawie rezultatów metaanalizy artykułów opublikowanych na łamach czasopisma naukowego Neofilolog, (w:) „Lingwistyka Stosowana/ Applied Linguistics/ Angewandte Linguistik" 12, 81-96. 
Orchowska, I. (2015b), O sytuowaniu epistemologicznym polskiego dyskursu glottodydaktycznego na temat kształcenia nauczycieli języków obcych, (w:) „Lingwistyka Stosowana/ Applied Linguistics/ Angewandte Linguistik" 14, 95-111.

Orchowska, I. (2017), De la spécificité épistémologique du discours métaglottodidactique. Entre autonomie intellectuelle des chercheurs et leur appartenance à la communauté scientifique polonaise, (w:) „Studia Romanica Posnaniensia" (przyjęty do druku).

Płusa, P. (1992), Doskonalenie umiejętności zawodowych nauczyciela języka francuskiego, (w:) „Neofilolog” 4, 74-77.

Pfeiffer, W. (2001), Nauka języków obcych. Od praktyki do praktyki. Poznań.

Piasecka, L. (1996), Pre-service teacher training: suggestions for M.A. degree seminars and theses, (w:) „Neofilolog” 12, 36-40.

Płusa, P. (1992), Doskonalenie umiejętności zawodowych nauczyciela języka francuskiego, (w:) „Neofilolog” 4, 74-77.

Puren, C. (1994), La didactique des langues à la croisée des méthodes. Essai sur l'éclectisme. Paris.

Rozporzadzenie Ministra Nauki i Szkolnictwa Wyższego z dnia 8 sierpnia 2011 r. w sprawie obszarów wiedzy, dziedzin nauki i sztuki oraz dyscyplin naukowych i artystycznych.

(http://www.nauka.gov.pl/g2/oryginal/2013_05/748f846e0255320d2846109ed37 2a25d.pdf). [Pobrano 10.05.2017].

Schön, D. (1983), The Reflective Practitioner. How Professionals Think in Action. London.

Strzałka, A. (2004), Zintegrowanie nauczania języka i kultury, (w:) „Neofilolog” 25, 6-9.

Wilczyńska, W. (2002), Słowniczek najważniejszych pojęć dotyczacych autonomizacji, (w:) W. Wilczyńska (red.), Autonomizacja w dydaktyce języków obcych. Doskonalenie się w komunikacji ustnej. Poznań, 317-335.

Wilczyńska, W. (2010), Obszary badawcze glottodydaktyki, (w:) „Neofilolog” 34, 21-35.

Wilczyńska, W./ A. Michońska-Stadnik (2010), Metodologia badań w glottodydaktyce. Wprowadzenie. Kraków.

Zając, J. (2008), L'orientataion anthropologique de la didactique des langues et ses implications interdisciplinaires, (w:) K. Bogacki/ B. Głowacka/ D. Potocka (red.), Interdisciplinary Perspectives in Foreign Language Teacher Education. Białystok, 147-160.

Zając, J. (2010). Glottodydaktyka w ujęciu epistemologicznym, (w:) „Neofilolog” 34, 37-48.

Zawadzka, E. 2004. Nauczyciele języków obcych w dobie przemian. Kraków.

Zawadzka-Bartnik, E. (2014), Refleksja w zawodzie nauczyciela-założenia a realne możliwości realizacji, (w:), „Neofilolog” 43/1, 7-23. 